\begin{tabular}{|c|c|c|c|c|c|}
\hline THE & SOCIETY & FOR & HOSPITAL & EPIDEMIOLOGY & AMERICA \\
\hline PResident & \multicolumn{3}{|c|}{ Donald E. Craven, MD/Boston, Massachusetts } & Treasurer & rutyn, MD/Philadelphia, Pennsylvania \\
\hline President-Elect & \multicolumn{3}{|c|}{ Peter A. Gross, MD/Hackensack, New Jersey } & COUNCILOR & D. Decker, MD/Nashville, Tennessee \\
\hline Vice PREsident & \multicolumn{3}{|c|}{ Bryan F! Simmons, MD/Memphis, Tennessee } & COUNCILOR & . Herwaldt, MD/Iowa City, Iowa \\
\hline Past President & \multicolumn{3}{|c|}{ John P. Burke, MD/Salt Lake City, Utah } & CoUncilor & Lettau, MD/Greenville, South Carolina \\
\hline SECRETARY & \multicolumn{3}{|c|}{ Dale N. Gerding, MD/Chicago, Illinois } & Councilor & Deery, MD/Peroskey, Michigan \\
\hline
\end{tabular}

\title{
Imporeminder for the Third Annual SHEA Meeting in Chicago
}

The meeting will be held from Sunday, April 18, to Tuesday, April 20, 1993. The deadline for receipt of abstracts has passed, but March 5,1993 , is the deadline for "Late Breaker" abstracts on recent investigations or studies of national importance. The deadline for discounted Palmer House reservations for the SHEA

Meeting is March 17, 1993. The

hotel's reservation phone number is (312) 7267500 or Hilton

Reservations at 1-800-445-8667.

The deadline for advance registration for the meeting at early-bird rates is March 26, 1993. Additional registration material or abstract forms can be obtained by calling the SHEA Meetings Department at (609) 8451720 or faxing to (609) 853-0411. The March issue of the SHEA Newsletter will have final details about the Annual Meeting.

\section{Job Market, Augusta VAMC}

The Augusta VAMC, a Dean's committee medical center physically attached to the Medical College of Georgia (MCG) Hospital, is recruiting for a hospital epidemiologist. The Augusta VAMC is a two division, 1,033 bed facility. Three infection control practitioners, one secretary and one program clerk (data entry) are employed full time. There is an active open-heart program, advanced cancer chemotherapy, specialized HIVAIDS clinic and an active internal medicine residency program with MCG. The VA's medicine teaching 